УДК 329.17

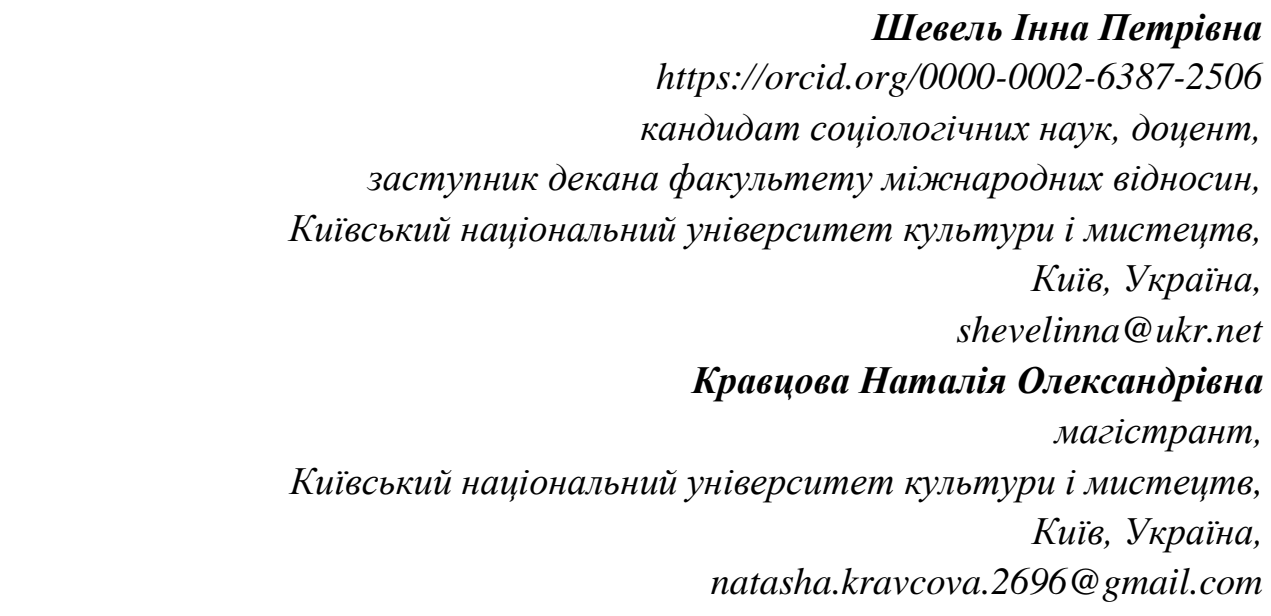

\title{
КРИМСЬКОТАТАРСЬКЕ ПИТАННЯ У МІЖДЕРЖАВНИХ ВІДНОСИНАХ ТУРЕЧЧИНИ ТА УКРАЇНИ
}

У статті розкрито питання самовизначення кримських татар, їх становище на території Автономної Республіки Крим та відношення України до діаспори кримських татар. Проаналізовано політику Туреччини, спрямовану на захист тюркських етносів, які проживають на території України.

Розглянуто постанову «Про Заяву Верховної Ради України щодо гарантії прав кримськотатарського народу у складі Української держави» від 20 березня 2014 року.,основною метою якої є збереження і розвиток етнічної, культурної, мовної та релігійної самобутності кримських татар як корінного народу i всіх національних меншин України. 3`ясовано, що основним принципом, покладеним в основу цього документу, $€$ реалізацію права на самовизначення кримськотатарського народу в складі України.

Проаналізовано діяльність ТІКА - Турецького агентство співпраці й координації в Україні , зокрема допомогу, надану кримським татарам .

Зроблено висновки, що Кримськотатарське питання є важливим об'єднавчим фактором відносин України та Туреччини.

Ключові слова: кримські татари, національні меншини, Турецьке агентство співпраці й координації в Україні. діаспора кримських татар. 
Shevel Inna, Candidate of Sociological Sciences, Associate Professor, Deputy Dean of the International Relations Faculty, Kyiv National University of Culture and Arts, Kyiv, Ukraine

Kravtsova Nataliia, Master Degree Student, Kyiv National University of Culture and Arts, Kyiv, Ukraine.

The Crimean tatar issue in inter-state relations between Turkey and Ukraine

The article deals with the issues of the Crimean Tatars self-determination, their position on the territory of the Autonomous Republic of Crimea and the attitude of Ukraine to the Crimean Tatars diaspora. It reveals the policy of Turkey, aimed at protection of the Turkish ethnic groups living on the territory of Ukraine.

The resolution "On the Statement of the Verkhovna Rada of Ukraine concerning the guarantee of the rights of the Crimean Tatar people as part of the Ukrainian state" dated March 20, 2014 was analyzed. It is stated that the basic principle laid down in the basis of this document is the realization of the right to self-determination of the Crimean Tatar people in the composition of Ukraine.

The activities of TIKA - the Turkish Agency for Cooperation and Coordination in Ukraine, in particular, assistance provided to the Crimean Tatars, are analyzed.

It is concluded that the Crimean Tatar issue is an important unifying factor in relations between Ukraine and Turkey.

Key words: Crimean Tatars, national minorities, the Turkish Agency for Cooperation and Coordination in Ukraine, diaspora of the Crimean Tatars.

Шевель Инна Петровна, кандидат социологических наук, доцент, заместитель декана факультета международных отномений, Киевский национальный университет культуры и искусств, Киев, Украина

Кравцова Наталья Александровна, магистрант, Киевский национальный университет культуры и искусств, Киев, Украина

Крымскотатарский вопрос в межгосударственных отношениях Турции и Украины

В статье раскрыты вопросы самоопределения крымских татар, их положение на территории Автономной Республики Крым и отношение Украины к диаспоре крымских татар. Проанализировано политику Турции, направленную на защиту тюркских этносов, проживающих на территории Украины.

Рассмотрено постановление «О Заявлении Верховной Рады Украины относительно гарантии прав крымскотатарского народа в составе Украинского государства» от 20 марта 2014 года, основной целью которого является сохранение и развитие этнической, культурной, языковой и религиозной самобытности крымских татар как коренного народа и всех национальных меньшинств Украины . Выяснено, что основным принципом, положенным в основу этого документа, 
является реализация права на самоопределение крымскотатарского народа в составе Украины.

Проанализирована деятельность ТИКА - Турецкого агентство сотрудничества и координации в Украине, в частности помощь, оказанную крымским татарам .

Сделаны выводы, что крымскотатарский вопрос является важным объединяющим фактором отношений Украины и Турции.

Ключевые слова: крымские татары, национальные меньшинства, Турецкое агентство сотрудничества и координации в Украине, диапора крымских татар.

Вступ. Захист інтересів кримськотатарської етноспільноти є об єднуючим елементом, який сприяє поглибленню міждержавних відносин Туреччини та України. Важливим фактором кримськотатарського етнополітичного процесу $€$ іноземний вплив Турецької Республіки, історично пов'язаної 3 даною етноспільнотою. Об'єктом даного дослідження є кримські татари - етноспільнота, яка є корінним народом Криму, проживає на півострові та становить майже $15 \%$ (300 тис.осіб) його населення. Кримський півострів історично вважається єдиною етнічною батьківщиною кримських татар. Через анексію півострову Крим та необхідність врегулювання статусу кримських татар, їх політична позиція та етнополітичне становище потребують детального розгляду та викликають інтерес у науковців,політиків та державних діячів.

Аналіз останніх досліджень і публікацій. Окремі аспекти проблеми захисту інтересів кримських татар, які проживають на території Кримського півострову досліджено в роботах українського вченого О. Шевчука, російського науковця К. Ахмадеева, турецького вченого Кірімлі Хакана, британського науковця Ендрю Вілсона та багатьох інших. Складна політична ситуація, в якій опинилося корінне населення Кримського півострова потребує більш детального і скурпульозного вивчення.

Постановка завдання. Метою статті $\epsilon$ аналіз пріоритетних векторів розвитку співробітництва між Україною та Туречинною у сфері врегулювання становища, в якому опинилися кримські татари внаслідок анексії Росією півосторову Крим у 2014 році.

Виклад основного матеріалу дослідження. Важливим фактором, який впливає на процес формування геополітичного становища регіону, традиційно вважають розташування держави та впливовість сусідніх країн. Туреччина $\epsilon$ активним геополітичним сусідом України, який має значний вплив на соціальні та політичні процеси в державі (Vitman, 2014). Географічне розташування Криму в Причорноморському регіоні дає можливість контролювати Азово-Керченську акваторію, а також забезпечує вихід до проток Босфор і Дарданелли. Британський науковець Ендрю Вілсон вважає,що ключову роль у реалізації зовнішньої політики 
Туреччини стосовно врегулювання становища кримських татар відіграє політика «м'якої сили» (Wilson, 2017).

Фактор турецького впливу на кримсько-татарський етнополітичний процес посилюється не лише історичним зв язком народів Туреччини та Криму, а й значною діаспорою в самій Туреччині. Дані про кількість проживаючих в Туреччині кримських татар різняться. На території цієї країни $є$ ряд анклавів, населених як самими кримськими татарами, так і багатьма спорідненими 3 ними народами. Також необхідно враховувати той факт, що офіційна національна політика турецької влади спрямована на аккультурацію і асиміляцію нетурецького населення, а дані про етнічний склад Туреччини офіційно не публікуються. На думку О. Шевчука, Туреччина розвиває відносини з кримськими татарами як зі своєю діаспорою і тому не лише лобіює інтереси кримських татар, а й враховує це в впровадженні своєї геополітичної стратегії в Причорноморському регіоні (Shevchuk, 2012). Найважливішим джерелом впливу Туреччини на кримськотатарський етнополітичний процес традиційно $є$ ідеологія пантюркизму, яка полягає в прагненні політичної, економічної, культурної та етнічної інтеграції тюркських народів, в якій домінуюча роль належить Туреччини як найбільш розвиненій з геополітичної $\mathrm{i}$ соціально-економічної точки зору державі з переважаючим тюркським компонентом (Kirimli, 2003).

Сучасний вплив Турецької Республіки на півострів Крим $є$ частиною «м'якої сили» Туреччини, активізація якої почалася з моменту розпаду СРСР і утворення нових незалежних держав, що мають в своєму складі значний тюркський сегмент. Як зазначив в $1992 \mathrm{p}$ прем'єр-міністр Туреччини С. Демірель, «Туреччина розшириться, незважаючи на те, що кордони залишаться незмінними. Іншими словами, Туреччина розширить свій вплив від Адріатики до Великої Китайської стіни»(Gürler).

Можемо провести аналогію діаспоральної політики Туреччини на Балканах та на території Кримського півострову. Турецька влада за допомогою засобів, спрямованих на покращення життя представників тюркських народностей, які проживають в різних країнах, прагне поширити власні сфери впливу, зокрема в Україні та Болгарії. В науковій праці Я. Волкової автор зазначає, що концептуальною основою зовнішньої політики Туреччини $\epsilon$ намагання повернути домінуючі позиції Туреччини на міжнародній арені,загублені з розпадом Османської імперії (Volkova, 2018).

Агентом впливу з Туреччини на кримсько-татарський етнополітичний процес можна вважати діаспору, яка проживає в цій країні. Кількість представників кримськотатарської діаспори в Туреччині сягає більш ніж 1 млн осіб. Серед представників турецької еліти чимало осіб, які мають кримськотатарське коріння (Boldyrev). Прихильність до історичної батьківщини збереглася в національній пам'яті діаспори, на що вказує відомий фахівець в області вивчення діаспор 
У. Шафран: «Базовими рисами діаспори $є$ наявність у представників етнічної громади етнічної самосвідомості, а також більш-менш чіткого образу історичної батьківщини. При цьому прихильність історичній батьківщині може зберігатися в національній самосвідомості діаспори на рівні історичної пам'яті, яка на різних етапах стає основою для пропаганди ідей репатріації. Як правило, представники діаспори мають проблемні стосунки з навколишнім етнокультурним середовищем, в якому вони проживають, сприймаючи його як загрозу асиміляції»( Safran, 1991).

Каналами впливу кримськотатарської діаспори в Туреччині є гуманітарні організації. Одна 3 них - «Союз культури і взаємодопомоги кримських тюрків», основними декларованими завданнями якого є надання підтримки співвітчизників в Криму і збереження етнічної культури кримських татар. Аналогічна взаємодія відбувається і по лінії молодіжних структур. Державним органом Туреччини по реалізації державної політики щодо кримськотатарської етноспільноти в Криму є Агентство 3 міжнародного розвитку та співробітництва при Раді міністрів Туреччини - Türkiye İşbirliği ve Kalkınma İdaresi (TİKA). Хоча робота даного органу і поширена на багато регіонів, серед яких Балкани, Північна Африка, Близький і Середній Схід, Східна Свропа, Причорномор'я, Північний і Південний Кавказ, Центральна Азія і Поволжя, Криму приділяють найбільше уваги. Дана організація є механізмом співпраці між державними установами, університетами, неурядовими організаціями та приватним сектором. Фінансування організації зростає: якщо в 2002 р обсяг коштів, що виділяються на міжнародні проекти, становив 85 млн. дол. США, то в 2015 р. він склав 3913 млн дол. США (Türk İşbirliği ve Koordinasyon Ajansı Başkanlığı). Фінансовий аспект впливу Туреччини на кримськотатарський етнополітичний процес полягає в залученні по каналах ТїКА значних інвестицій в економіку Криму. Контрагентом турецько-кримсько-татарської взаємодії в Криму $\epsilon$ «Меджліс кримсько-татарського народу», який виступає посередником в процесі залучення турецького капіталу на півострів. Одночасно 3 активізацією роботи агентства на кримському «майданчику» під егідою «Меджлісу» був створений фонд «Крим», головою якого став М. Джемілєв. Фонд виступає в ролі основного партнера TİKA не тільки в Криму, але і в цілому на території України» (Türk İşbirliği ve Koordinasyon Ajansı Başkanlığgı).

3 метою захисту інтересів кримських татар ще у травні 2009 р. у місті Сімферополь було створено Всесвітній Конгрес кримських татар (ВККТ). Делегатипредставники понад 160-ти кримськотатарських організацій, яких налічувалось близько 800 осіб 312 країн, під час роботи конгресу ухвалили Декларацію Всесвітнього Конгресу кримських татар. В даному документі зазначалося, що основною метою організації (ВККТ) є об єднання та координація зусиль громадських організацій кримських татар в різних країнах, які прагнуть співпрацювати відповідно до цілей, принципів та завдань, вказаних у декларації. Під час засідання було підписано Звернення до Президента України, в якому 
наголошувалось на необхідності відновлення прав кримськотатарського народу (Chy prokovtne Kreml Vsesvitnii konhres krymskykh tatar). Другий Всесвітній конгрес кримських татар відбувся в Анкарі у серпні 2015 р., в результаті роботи якого було оприлюднено звернення учасників до світової спільноти із проханням сприяти здійсненню усіх необхідних заходів з метою термінового припинення протиправної окупації Російською Федерацією Кримського півострова (Uchasnyky Vsesvitnoho Konhresu krymskykh tatar...).

Варто зазначити, що з перших днів інтервенції Російської Федерації на територію Автономної Республіки Крим, яка завершилася анексією півострову Росією, кримськотатарська еліта та представницькі органи кримськотатарського народу негативно поставились до приєднання Криму до складу Російської Федерації. Як відомо, 16 березня 2014 року на території Автономної Республіки Крим відбувся нелегітимний референдум про статус Криму. Маємо інформацію, що близько 99 \% кримськотатарського населення проігнорували референдум та не визнали його результати (Krymskie tatary provedut svoi referendum...).

Після референдуму представники кримськотатарського народу почали поступово залишати територію півострова та виїжджати до континентальної України. За офіційними даними близько 25 тисяч кримських татар після проведення референуму почали поступово залишати територію півострова та виїжджати до континентальної України (Pro Zaiavu Verkhovnoi Rady Ukrainy...).

Важливим законодавчим актом у кримськотатарському питанні стала прийнята 20 березня 2014 р. Верховною Радою України Постанова «Про Заяву Верховної Ради України щодо гарантій прав кримськотатарського народу у складі Української держави», яка гарантує захист і реалізацію невід'ємного права на самовизначення кримськотатарського народу в складі суверенної і незалежної Української держави. Цією Постановою Верховна Рада України доручила Кабінету Міністрів України терміново подати проекти законів України, нормативно-правових актів України, які визначають та закріплюють статус кримськотатарського народу як корінного народу України (Pro Zaiavu Verkhovnoi Rady Ukrainy...).

Позитивним також у цьому напрямку слід визнати Указ Президента України Петра Порошенка від 3 листопада 2014 р. № 841/2014 «Про Положення про Уповноваженого Президента України у справах кримськотатарського народу», де, окрім прописаних повноважень Уповноваженого, наголошується на тому, що кримськотатарський народ $є$ корінним народом України. У Положенні, зокрема, зазначається, що «Уповноважений Президента України у справах кримськотатарського народу забезпечує здійснення Президентом України повноважень щодо забезпечення додержання конституційних прав кримськотатарського народу як корінного народу України» (Pro Polozhennia pro Upovnovazhenoho Prezydenta Ukrainy...). Але до цього часу не прийнятим залишається ініційований народним депутатом України, національним лідером 
кримських татар Мустафою Джемілєвим Проект Закону про «Концепцію державної етнонаціональної політики України», поданий на розгляд ВР 4 липня 2013 р., який визначає зміст і дії держави в етнополітичній сфері та є основою для формування нового законодавства, вдосконалення міжетнічних відносин.

У лобіюванні інтересів кримських татар на державному рівні важливу роль відіграє Мустафа Джемілєв, Уповноважений Президента України у справах кримськотатарського народу, який раніше очолював Меджліс кримськотатарського народу. Мустафа Джемілєв $з$ початку 1960-pp. і до сьогодні бере активну участь у кримськотатарському національному русі. Разом із теперішнім головою Меджлісу Рефатом Чубаровим вони є організаторами мітингів стосовно деескалації ситуації у Криму. За участі Мустафи Джемілєва було засновано загони самооборони 3 кримських татар. Враховуючи значні досягнення лідера кримськотатарського народу, Президент Туреччини особисто нагородив Мустафу Джемілєва Орденом Республіки Туреччина за заслуги у питаннях розвитку співробітництва між Туреччиною та Україною (Türkiye'yi eski karanlık günlerine döndürmek isteyenler...).

Важливу роль турецька влада відіграє у поверненні кремлівських в язнів на території України .Після переговорів між Президентом Турецької Республіки Ердоганом та Президентом Російської Федерації Путіним Ахтем Чийгоз (заступник голови Меджлісу Кримськотатарського народу та голова Бахчисарайської районої державної адміністрації) та Ільми Умеров (депутат Бахчисарайської районої державної адміністрації),які в травні 2016 р. були затримані Федеральною службою безпеки Російської Федерації через їх висловлювання стосовно посилення санкцій стосовно Російської Федерації, були передані Туреччині восени 2017 р. Українська влада сподівається на допомогу Президента Туреччини у поверненні на Батьківщину інших політичних заручників Росії. Для Ердогана допомога у звільненні українських політв'язнів може стати важливим іміджевим ходом для покращення репутації на Заході та розвіювання образу диктатора (Erdogan budet pomagat' v osvobozhdenii polituznikov).

Президенти України та Турецької Республіки під час численних зустрічей неодноразово обговорювали питання врегулювання становища,в якому опинилися кримські татари внаслідок анексії Росією півосторову Крим.Зокрема, під час останнього візиту Петра Порошенка до Стамбулу, який відбувся 3 листопада 2018 р., Президент України та Президентом Туреччини (Реджеп Раїп Ердоган) обговорили шляхи вирішення ситуації,в якій опинилися кримські татари внаслідок окупації Криму (Poroshenko u Stambuli provodyt zustrich z Erdohanom). Взагалом позицію Президента Туреччини щодо анексії Криму можна вважати стабільно проукраїнською, зважаючи на зусилля, які він докладає задля повернення кремлівських в`язнів на Батьківщину та неодноразові заяви Ердогана стосовно підтримки територіальної цілісності України . 
Висновки. Зважаючи на складну геополітичну ситуацію навколо України, що склалася після анексії Криму у 2014 р., зросла необхідність міжнародного співробітництва у сфері захисту інтересів кримськотатарського етносу. Відповідно, становище в якому внаслідок політичного конфлікту між Україною та Росією опинилися кримські татари, є одним із тих факторів, що спонукав Турецьку Республіку виступати на захисті українського суверенітету.

\section{References:}

1. Boldyrev, A. 'Krymskii faktor v rossiisko-turetskikh otnosheniyakh' [Crimean factor in Russian-Turkish relations], [online] Available at: http://militariorg.ucoz.ru/publ/ukraina_krym_rossija/krymskij_faktor_v_rossijsko_tureckik h_otnoshenijakh/17-1-0-29288 [Accessed 27 September 2018].

2. Chy prokovtne Kreml Vsesvitnii konhres krymskykh tatar [Will the Kremlin swallow the World Congress of Crimean Tatars]. (2015). Krym. Realii, [online] Available at: <https://ua.krymr.com/a/26945264.html> [Accessed 11 October 2018].

3. Erdogan budet pomagat' v osvobozhdenii polituznikov [Erdogan will help in the liberation of the military]. Agentstvo "Krymskie novosti" [Crimean News Agency], [online] Available at: <http://qha.com.ua/ru/politika/erdogan-budet-pomogat-vosvobojdenii-polituznikov-klimkin/193495> [Accessed 27 October 2018].

4. Gürler, R. T. 'Turkey's Soft Power towards Central Asian Countries after the Cold War', [online] Available at <www.uli.sakarya.edu.tr/sites/uli.sakarya.edu.tr/file/1371681799-recepgurler.pdf> [Accessed 27 October 20180.

5. Kirimli, H. (2003). 'Turko-Ukrainian Relations and the Crimean Tatars'. International Committee for Crimea, [online] Available at:〈http://www.iccrimea.org/scholarly/tuarel-hakan.html> [Accessed 23 October 2018].

6. Krymskie tatary provedut svoi referendum po statusu Kryma [Crimean Tatars will hold their referendum on Crimean status]. (2014). Censor.net, [online] Available at: <https://censor.net.ua/news/278168/krymskie_tatary_provedut_svoyi_referendum_po_stat usu_kryma_djemilev> [Accessed 16 October 2018].

7. Pislia okupatsii Krymu zvidty vyikhalo blyzko 25 tys. krymskykh tatar [After the occupation of the Crimea about 25 thousand Crimean Tatars left it]. (2018). Depo.ua, [online] Available at: $<$ https://www.depo.ua/ukr/life/pislya-okupaciyi-krimu-zvidtiviyihalo-blizko-25-tis-krimskih-tatar-20180513773086> [Accessed 17 October 2018].

8. Poroshenko u Stambuli provodyt zustrich z Erdohanom [Poroshenko in Istanbul holds a meeting with Erdogan]. (2018). Yevropeiska Pravda [European truth], [online] Available at: <https://www.eurointegration.com.ua/news/2018/11/3/7088951> [Accessed 5 November 2018].

9. Pro Polozhennia pro Upovnovazhenoho Prezydenta Ukrainy u spravakh krymskotatarskoho narodu № 841/2014 [On the Regulations on the Authorized President 
of Ukraine on Crimean Tatar People's Affairs no. 841/2014]. Ukaz Prezydenta P. Poroshenka [Decree of President P. Poroshenko] (2014, November 3), [online] Available at:<http://zakon2.rada.gov.ua/laws/show/841/2014> [Accessed 20 October, 2018].

10. Pro Zaiavu Verkhovnoi Rady Ukrainy shchodo harantii prav krymskotatarskoho narodu u skladi Ukrainskoi Derzhavy [On Statement of the Verkhovna Rada of Ukraine re guarantees of rights of the Crimean Tatar people as a part of the State of Ukraine]. Postanova Verkhovnoi Rady Ukrainy [The Resolution of the Verkhovna Rada of Ukraine]. (2014, March 20), [online] Available at:< http://zakon2.rada.gov.ua/laws/show/1140-18> [Accessed 20 October, 2018].

11. Safran, W.(1991). 'Diasporas in Modern Societies: Myths of Homeland and Return'. Diaspora: A Journal of Transnational Studies, Vol. 1, no. 1, Spring, pp. 83-99. DOI:http://doi.org/10.1353/dsp.1991.0004.

12. Shevchuk, O.H. (2012). 'Ohliadovo-analitychna otsinka potochnoi sotsiokulturnoi i etnokonfesiinoi sytuatsii $\mathrm{v}$ heopolitychnomu prostori' [An overviewanalytical assessment of the current socio-cultural and ethno-confessional situation in the geopolitical space]. Pytannia rozvytku Krymu [Problems of Crimea], issue 16, pp. 275-282.

13. Türk İşbirliği ve Koordinasyon Ajansı Başkanlı̆̆g, [online] Available at:〈https://tika.gov.tr/tr/sayfa/hakkimizda-14649> [Accessed 30 September 2018].

14. Türkiye'yi eski karanlık günlerine döndürmek isteyenler, kendi karanlıklarında kaybolup gidecektir (2018). Ofitsiinyi sait Prezydenta Turechchyny [Official Website of the President of Turkey], [online] Available at: <https://www.tccb.gov.tr/> [Accessed 22 November 2018].

15. Uchasnyky Vsesvitnoho Konhresu krymskykh tatar pryinialy Zvernennia do svitovoi spilnoty [Participants of the World Congress of Crimean Tatars adopted the Appeal to the World Community]. (2015). 112.ua, [online] Available at:<https://ua.112.ua/polityka/uchasnyky-vsesvitnoho-konhresu-krymskykh-tatar-

pryinialy-zvernennia-do-svitovoi-spilnoty-povnyi-tekst-249273.html>

[Accessed 16 October 2018].

16. Vitman, K. M. (2014). 'Zmina statusu Avtonomnoi Respubliky Krym yak sposib vyrishennia etnopolitychnykh superechnostei' [Changing the status of the Autonomous Republic of Crimea as a way of solving ethnopolitical contradictions]. Aktualni problemy yevropeiskoi intehratsii [Actual problems of European integration], no. 7 , p. 276.

17. Volkova, Ya. O. (2018). Diasporalna polityka respubliky Turechchyna ta yii vplyv na bolharo-turetski vidnosyny [Dysasporal policy of the republic of Turkey and its influence on the Bulgarian-Turkish relations]. D.Ed. Odesa National University named after I. I. Mechnikov; Petro Mohyla Black Sea National University. 
18. Wilson, A. (2017). 'The Crimean Tatar Question:A Prism for Changing Nationalisms and Rival Versions of Eurasionism'. Journal of Soviet and Post-Soviet Politics and Society, Vol. 3, no. 2, pp. 1-45. DOI: 10.24216/97723645330050302_01.

(C) Шевель І. П., Кравцова Н. О., 2019 